influence of typological thinking.

All the leading schools of taxonomy have taken it for granted that classification is somehow based upon putting similar things together on the basis of shared attributes, and nothing else. There is little hope for rectifying the situation until the falsehood of this premise is generally recognized. Classifications ought to be based upon a scientific evaluation of any data that happen to be germane; that is, upon scientific knowledge as a whole, drawing upon physics and chemistry, as well as the laws, principles and historical particulars of biology and geology. It means thinking like a historian, asking what has happened and why, and formulating hypotheses and gathering data to test them.

There are innumerable opportunities available for doing the job well. At the moment the study of large molecules apt to evolve divergently is beginning to yield very impressive results. Charles Sibley's monumental work on DNA $\times$ DNA hybridization in birds has at last provided us with a rigorous phylogeny of the group, this in spite of the fact that it does not employ shared derived characters and has therefore been spurned by the cladists. It works instead because, as time passes, homologues cease to be identical, and the relevant parameters can be measured. Likewise Carl Woese's frontal attack on prokaryote ribosomal RNA has demolished the claims of pheneticists that bacterial phylogenetics is simply unknowable. Norman Pace has developed a technique whereby hundreds of nucleotides of this same material can be read off a single gel, and data on the phyla and classes of Metazoa are rapidly accumulating in his laboratory. Once the basic phylogenetic tree has been worked out, biologists will then find it much easier to place the whole range of their findings in an evolutionary context. When that happens, the value of genealogy will be so clear that its alternatives will no longer be taken seriously. Good science generally wins out over bad philosophy, but it takes a long time.

Michael T. Ghiselin is MacArthur Fellow in the Department of Invertebrate Zoology, California Academy of Sciences, Golden Gate Park, San Francisco, California 94118, USA.

\section{Dancing in time}

\section{Leonard Krishtalka}

The Great American Biotic Interchange. Edited by Francis G. Stehli and S. David Webb. Plenum:1985. Pp.532. \$75, £61.64.

FOR THE past 90 million years (Myr) North and South America have danced a biological and geological pas de deux - long periods of drifting in isolation punctuated by brief encounters, animal invasions and faunal interchange. Until quite recently, much of the palaeobiological ballet of the Americas was scattered throughout a vast literature. Not any more. The Great American Biotic Interchange is an outstanding reference work on $90 \mathrm{Myr}$ of New World faunas, geochronology and palaeogeography, especially of South America. It is appropriately dedicated to George Gaylord Simpson and complements his more popular book on the subject, Splendid Isolation: The Curious History of South American Mammals, published by Yale University Press in 1980.

The volume opens in the late Cretaceous. By that time plate tectonics and a spreading Atlantic sea floor had torn the Americas from Europe and Africa and waltzed them into momentary contact across a Caribbean island arc. The fossil record hints that South American didelphid marsupials hopscotched into North America for the first time, while northern lizards, snakes, duckbilled dinosaurs and a primitive placental ungulate entered South America.
The Americas jetéd apart for the next 87 million years, their faunas evolving in near isolation from one another. North America became dominated by placental mammals: primates (initially), insectivores, rodents, rabbits, perissodactyls, artiodactyls, mastodons and a legion of now extinct orders. South America hosted the explosive radiation of a horde of marsupials, edentates (sloths, anteaters, armadillos) and unusual, now extinct, placental ungulates (hoofed herbivores: didolodonts, astrapotheres, litopterns, notoungulates and pyrotheres).

Three events pierced the calm of faunal isolation. The first, of least consequence, seemingly occurred in the mid-Palaeocene (58-61 Myr ago), when edentates and notoungulates appear to have islandhopped to North America from the south, left a few tantalizing bony remains and continued on to Asia. The second episode, during the mid- to late Oligocene (33-28 Myr ago), involved the sudden appearance in South America of platyrrhine primates and caviomorph rodents, immigrants on a flotilla of "Noah's Arks" biotic rafts - from North America or Africa. The third event, during the late Miocene (7-9 Myr ago), was a portent of things to come: a filter bridge between the Americas allowed some racoons and rodents to pass south and two groups of sloths to move north.

Three million years ago the Panamanian land corridor surfaced and all pretence of faunal isolation ended; the Great American Interchange was underway. Among the first waves of northern mammals to invade South America were canids, ursids, mustelids, felids, tapirs, equids, camelids, cervids and mastodons. In turn, rodents (porcupine, capybara), edentates (glyptodonts, ground sloths, armadillos), a llama, an opossum and a flightless bird dispersed into North America.

Peppering this history are palaeoecological questions: the convergent suites of morphological adaptations among mammalian ecological vicars in North and South America; the allegedly precocious evolution in South America of savannahs and grazing ungulates with high-crowned dentitions; the effects, if any, of the northern placental invaders on southern faunas; and the ancestors, provenance and date of arrival of the first South American primates and rodents.

Unlike the scattershot approach of most symposium volumes, the material in the book is organized in textbook fashion (19 chapters in five sections). Sections I and II examine Caribbean plate motions; plate evolution; evidence of inter-American mammals in the Palaeocene; herpetofaunas from the Cretaceous and the Cenozoic; and geochronology, mammalian biochronology and interchange events for the same periods. The last two (by R. Estes and A. Báez, and L.G. Marshall) are excellent and exhaustive treatments.

Section III covers the Tertiary evolution and dispersal of North American mammals; the origin and diversification of South American mammals, ungulates, and primates and rodents. Here nationalism seems to reign. Most American palaeontologists, including A.E. Wood who deals with primates and rodents, claim a New World mid-Tertiary origin for the South American platyrrhines and caviomorphs. Old World palaeobiologists favour an African origin.

The last two sections are the climax close looks at the physical and biotic dynamics of the Great American Interchange over the past 3 Myr: Caribbean tectonics; the Central American land bridge, climate and sea level; the interAmerican dispersal of invertebrates, plants and their bee pollinators, fish, amphibians and reptiles, birds, all mammals, and desert and grassland mammals.

Accompanying the integrated accounts of palaeobiology, biogeography, ecology, systematics and geology is a staggering amount of information, such as the detailed compendia of fossil vertebrate occurrences in South America. The Great American Biotic Interchange is a comprehensive, up-to-date and invaluable resource for any student interested in the past and present biotas of the Western hemisphere.

Leonard Krishtalka is Associate Curator in the Section of Vertebrate Fossils, Carnegie Museum of Natural History, 4400 Forbes Avenue, Pittsburgh, Pennsylvania 15213, USA. 